\title{
Growth variation of Atlantic salmon Salmo salar at sea affects their population-specific reproductive potential
}

\author{
Philip Jacobson $^{1, *}$, Rebecca Whitlock ${ }^{2}$, Magnus Huss ${ }^{1}$, Kjell Leonardsson $^{3}$, \\ Johan Östergren ${ }^{2}$, Anna Gårdmark ${ }^{1}$
}

\author{
${ }^{1}$ Swedish University of Agricultural Sciences, Department of Aquatic Resources, Skolgatan 6, 742 42, Öregrund, Sweden \\ ${ }^{2}$ Swedish University of Agricultural Sciences, Department of Aquatic Resources, Stångholmsvägen 2, 178 93, Drottningholm, Sweden \\ ${ }^{3}$ Swedish University of Agricultural Sciences, Department of Wildlife, Fish and Environmental Studies, \\ Skogsmarksgränd, 907 36, Umeå, Sweden
}

\begin{abstract}
Understanding the processes shaping the dynamics of anadromous fish populations is essential for their management and conservation. Yet, little is known about how variation in performance at sea affects their population dynamics. Here we show that variation in body growth at sea contributes to explaining variation in the reproductive potential for 2 Atlantic salmon Salmo salar populations, but to a varying extent. To this end, we assembled data collected during $50 \mathrm{yr}$ for 2 Baltic salmon populations of hatchery origin, including annually released smolts, survival at sea estimates, size-specific growth at sea, annual length distributions of returning adult females and their reproductive potential. The regression models fitted to explain the reproductive potential of our 2 study populations improved when growth at sea was included as an explanatory variable, in addition to smolt year class abundance and estimates of their survival at sea. This link between body growth at sea and population-level reproductive potential suggests that growth at sea can be important to consider when resolving variation in recovery and dynamics among salmon populations sharing the same sea.
\end{abstract}

KEY WORDS: Anadromy $\cdot$ Fecundity $\cdot$ Population dynamics $\cdot$ Salmon $\cdot$ Size-specific body growth

\section{INTRODUCTION}

The dynamics of fish populations are governed by the loss and production of biomass, both of which are determined by the success of individuals to survive, grow, mature and spawn. Survival, growth and fecundity depend on body size and, therefore, will vary among differently sized individuals within fish populations (Lorenzen 1996, Persson \& de Roos 2013, Hixon et al. 2014). Accounting for these sizedependencies is thus paramount for understanding the dynamics of fish populations (Persson et al.

${ }^{*}$ Corresponding author: philip.jacobson@skb.se
2007, van Leeuwen et al. 2008, Ohlberger et al. 2011). However, assessing variation in performance at sea, such as survival and growth, using observational data and testing how such variation affects population dynamics is challenging, especially for species that migrate across habitats and have a wide distribution. Accordingly, for the iconic anadromous Atlantic salmon Salmo salar, we have limited knowledge about how variation in performance at sea affects their population dynamics (ICES 2010, Aas et al. 2011, Soto et al. 2018, Susdorf et al. 2018).

(C) The authors 2021. Open Access under Creative Commons by Attribution Licence. Use, distribution and reproduction are unrestricted. Authors and original publication must be credited. 
Many Atlantic salmon populations originating from rivers connected to the North Atlantic Ocean have declined in abundance in recent decades despite management actions aimed at improving spawning habitats and decreased commercial fishing at sea (Chaput 2012, Soto et al. 2018). This suggests that factors other than the amount of suitable spawning habitats and fisheries mortality contribute to these widespread declines (ICES 2010, Chaput 2012, Friedland et al. 2014, Soto et al. 2018). The estimated status among Atlantic salmon populations originating from rivers entering the Baltic Sea differs (the status is determined based on how close each population is to reaching $\geq 75 \%$ of its potential smolt production capacity), despite large reductions in fishing effort at sea in areas where these populations occur mixed (ICES 2019, Jacobson et al. 2020). The reasons why some of these Baltic salmon populations have recovered while others have not are poorly understood (ICES 2019). Population-specific changes in the performance of salmon at sea, e.g. via variation in growth (Jensen et al. 2018) or body condition (Todd et al. 2008, Bacon et al. 2009, Susdorf et al. 2018), could potentially contribute to the observed variation in the extent of decline or recovery in salmon abundance. Yet, we have limited knowledge regarding the relative importance of variation in individual level processes at sea, e.g. survival and growth, on the reproductive potential of Atlantic salmon populations.

It is well known that the body size of adult females governs their fecundity, as large female fish can produce larger gonads compared to small females (Thorpe et al. 1984, de Eyto et al. 2015, Barneche et al. 2018). Consequently, ensuring high survival rates to promote the existence of large and old females within harvested fish populations is important for safeguarding the continued existence of harvested populations (Hixon et al. 2014, Barneche et al. 2018). However, we currently do not know whether annual growth variation at sea also influences the reproductive potential of anadromous Atlantic salmon populations. Here we examine the contribution of body growth at sea, relative to smolt abundance and survival at sea, to the variation in annual reproductive potential for 2 anadromous Baltic salmon populations of hatchery-reared origin. To this end, we combined data collected over $50 \mathrm{yr}$ on the annual numbers of released smolts, growth data from tagged salmon recaptured at sea, population-, year class- and sea age-specific estimates of survival rates at sea, annual length distributions of the returning adult females and size-specific fecundity data.

\section{MATERIALS AND METHODS}

Our analyses are based on data collected during 5 decades for 2 hatchery-reared salmon populations originating from 2 rivers entering the Baltic Sea, the rivers Dalälven and Umeälven (hereafter referred to as Dalälven and Umeälven respectively, Fig. S3 in Supplement 1; Supplements 1-6 all available at www.int-res.com/articles/suppl/m671p165_supp. pdf). Because these are hatchery-reared populations, the number of juvenile individuals in freshwater is controlled for in the hatchery. The number, age and length of returning spawners are therefore governed by the annual number of released smolts, their age at maturation and their growth and survival at sea. The number of returning adult females and their size will, in turn, determine the reproductive potential (i.e. total amount of roe) of the population (Fig. 1). In both Dalälven and Umeälven, the large majority of returning adult females have experienced either 2 or 3 winters at sea ('sea winters', SW) before returning to spawn in their natal river (referred to as 2SW and 3SW individuals, respectively) (Table S1 in Supplement 1, Supplement 5). The returning adult females in both populations will, therefore, be largely dominated by individuals from 2 smolt year classes, being released 2 and 3 yr prior to a specific return year (Fig. 1, Table S1). Therefore, for any year of returns, we combined growth and survival data on individuals that were released 2 and 3 yr ago, along with the total number of released smolts from those years. These data were then used when testing whether variation in growth at sea contributes to explain variation in the reproductive potential in our 2 study populations.

\subsection{Study systems}

Both Dalälven and Umeälven have been exploited for hydroelectric power since 1915 and 1957, respectively (www.vattenkraft.info). Due to extensive damming, the possibily of natural production of salmon in Dalälven is limited. Still, some production occurs downstream of the first barrier that prevents further upstream migration, but the wild production is only about $1 \%$ of the production of hatchery-reared salmon in this river (Petersson et al. 1996). The Umeälven river divides into the Umeälven and Vindelälven shortly upstream of the first migration barrier. There is no natural production in Umeälven above this division due to the lack of suitable spawning habitat, though natural repro- 


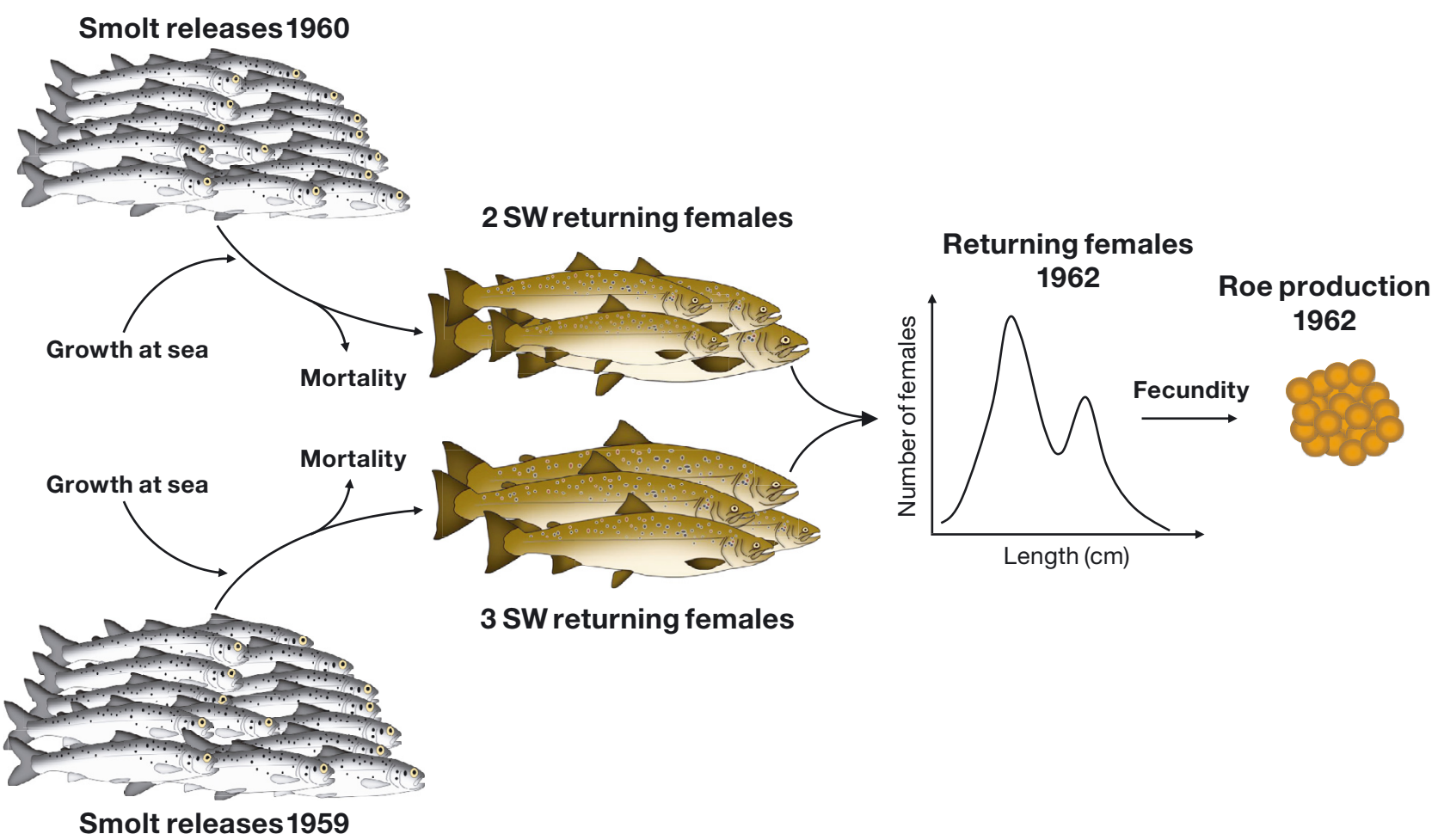

Fig. 1. Model of the salmon sea life phase and the potential influence of body growth, survival at sea and number of smolt releases on the reproductive potential of a salmon population. Annual number of released smolts (Fig. S6 in Supplement 3) in our 2 study rivers, Dalälven and Umeälven, was obtained from the hatcheries in each river. Data on growth at sea was calculated separately for our 2 study populations using mark-recapture data of salmon (Figs. S7 \& S8 in Supplement 3) released in Dalälven and Umeälven recaptured at sea. Survival at sea (Fig. S9 in Supplement 3) estimated using reported recaptures of tagged salmon at sea from each of our 2 study populations as input data in a modified version of the mark-recapture survival estimate model in Whitlock et al. (2017) (Supplement 4). Number and lengths of returning adult females (Supplement 1) were obtained from the broodstock fisheries conducted in each of our 2 study rivers. SW: sea winter

duction does occur in the unexploited Vindelälven (ICES 2019).

To compensate for the loss in natural production of Baltic salmon in both the Dalälven and Umeälven, the hydropower companies are legally obliged to rear and annually release salmon. Salmon smolts have been released annually in both rivers since the 1960s. Before the 1960s, salmon were released as eggs, fry, parr and smolt. All smolts are marked before release via removal of their adipose fin to enable visual determination of their origin (to differentiate them from wild salmon that have their adipose fin intact). To collect adults for rearing, broodstock fishing is carried out annually in both rivers using permanent fish traps connected to the first migration barrier. Consequently, as both hatcheries use adults that have returned from the sea to their natal river as broodstock, both of our study populations are genetically distinct from each other despite being hatchery reared (Ståhl 1987, Vasemägi et al. 2005, Whitlock et al. 2018, Östergren et al. 2020).

\subsection{Annual length distributions of returning adult females}

The adults returning to the rivers to spawn have been continuously monitored in the Dalälven and Umeälven since 1960 via the permanent traps. Length, weight, origin (hatchery or wild) and sex (visually assessed via secondary sexual characteristics, such as jaw morphology and body shape; Fleming 1996) have been recorded for all individuals caught. Before 1960 (1927-1959) no lengths of caught salmon were recorded in Dalälven. In Umeälven, no individual weights were recorded (these were instead estimated in $0.5 \mathrm{~kg}$ intervals based on their lengths) before 1972 . For this study, we used the observed lengths and total number of returning adult females of hatchery origin for each year and river (Supplement 1).

To calculate the annual reproductive potential of our 2 study populations in Dalälven and Umeälven, we combined data on the lengths of all returning adult females of hatchery origin in each river with 
size-specific individual fecundity data from Dalälven (fitting a locally weighted scatterplot smooth [LOESS] curve between female body length and kilogram produced roe to estimate size-specific fecundity, Supplement 2). We used individual fecundity data from Dalälven for both our study populations, as the sample size of fecundity data from Umeälven was small and roe biomass has not been recorded. By combining the length distributions of adult females returning to spawn and the size-specific model of individual fecundity, we calculated the annual total amount of roe that could be produced in each river, yielding the annual reproductive potential for hatchery-reared salmon in Dalälven and Umeälven, respectively.

\subsection{Smolt releases, survival and growth at sea}

\subsubsection{Annual smolt releases}

The number of released smolts (smolt year class abundance) varies across years and affects the potential number of returning hatchery-reared adult females. We accounted for this variation using data on the number of smolts released annually for Dalälven and Umeälven for the time period 1956-1999, which has been recorded in a database by the Swedish Salmon Research Institute, LFI (for Dalälven), and Åke Forssén (for Umeälven) (J. Östergren and J. Persson unpubl.). The annual number of released hatchery-reared salmon smolts varied between 2045 and 244895 (mean = 76 692) and 223 and 280845 (mean = 93464) individuals per year for Dalälven and Umeälven, respectively, during our study period (Fig. S6 in Supplement 3).

\subsubsection{Survival at sea}

The survival of smolts between the time they are released and the return to their natal rivers as adults depends on both natural and fisheries mortality. We accounted for this mortality, as it will affect the number and potentially the size distribution of returning adult females. To this end, we used an existing mark-recapture Bayesian model (Whitlock et al. 2016) to estimate the age-specific survival rates at sea for each smolt year class for Dalälven and Umeälven separately for the time period 1956-1999, based on releases and recaptures in the Swedish Carlin-tagging program (see section 2.3.3.). The model estimates both natural and fisheries mortality. It accounts for variation in the nat- ural mortality for 0+SW salmon at sea (same year as being released) but assumes an equal natural mortality for $1+$ SW salmon at sea (the year at sea after the release year) and $2+\mathrm{SW}$ salmon at sea (the second year at sea after the release year), which is the same assumption as in the current assessment model used for Baltic salmon populations by ICES WGBAST (Supplement 4; ICES 2018). The model estimates 2 survival rates per sea age and year, one for MarchAugust and one for September-February. Model configuration and parameters are attached as supplementary material (Supplement 4). We estimated the survival of 2SW and 3SW returning females from each smolt year class y (Fig. S9 in Supplement 3, Fig. S10A in Supplement 5) using the following equations:

$$
\begin{aligned}
& \operatorname{Surv}_{2 \mathrm{SW}, Y}=\operatorname{Surv}_{0+, Y} \times \operatorname{Surv}_{0+, y} \times \operatorname{Surv} 3_{1+, y} \times \operatorname{Surv} 4_{1+, y} \\
& \text { (Eq. 1) } \\
& \operatorname{Surv}_{3 \mathrm{SW}, Y}=\operatorname{Surv}_{0^{+, Y}} \times \operatorname{Surv}_{0+, Y} \times \operatorname{Surv} 3_{1+, Y} \\
& \times \operatorname{Surv}_{1+, Y} \times \operatorname{Surv}_{2+, Y} \times \operatorname{Surv6}_{2+, y} \quad \text { (Eq. 2) }
\end{aligned}
$$

where Surv1 $1_{0+}$ is the survival of smolt from time at release until August in the 0+SW year at sea (release year, $y$ ), Surv $2_{0+}$ is the survival from September in the $0+\mathrm{SW}$ year at sea until February in the $1+\mathrm{SW}$ year at sea, Surv $3_{1+}$ is the survival for March-August in the $1+\mathrm{SW}$ year at sea, Surv4 $4_{1+}$ is the survival from September in the $1+\mathrm{SW}$ year at sea until February in the $2+\mathrm{SW}$ year at sea, Surv $5_{2+}$ is the survival for March to August in the 2+SW sea year and Surv6 $2_{2+}$ is the survival from September in the $2+\mathrm{SW}$ year at sea to February in the 3+SW sea year (Fig. S10A).

\subsubsection{Growth at sea}

For both Dalälven and Umeälven, growth at sea was retrieved from analyses of recaptures in the Swedish Carlin tagging program, initiated in 1951 (Larsson 1984). In this program, hatcheries tagged a proportion of reared and released smolts with Carlin tags (Karlsson \& Karlström 1994, Romakkaniemi et al. 2003), which are attached externally underneath the dorsal fin and carry a unique number and instructions for reporting the catch. At the tagging event, the river-of-origin, length, age, release location and date were recorded. Catchers of tagged individuals are instructed to return the tag together with date, length, weight, type of fishing (e.g. recreational, commercial or scientific) and recapture location, together with any additional comments. Until 1999, LFI managed the database containing all releases and recaptures of tagged individuals; thereafter the hydropower 
companies have managed the database. After 1999, the recapture report rate, data quality and availability have decreased (ICES 2013). Here, we have managed to retrieve sufficient recapture data of $1+\mathrm{SW}$ and $2+$ SW-aged salmon at sea for smolt year classes released in 1967-1993 for Dalälven (total amount of recaptures = 3425) and 1956-1997 for Umeälven (total amount of recaptures $=7170$ ) (Figs. S7 \& S8, Supplement 5).

To assess the growth of salmon at sea, we calculated the size-specific growth (SSG,\% length increase) (Lugert et al. 2016) for 1+SW salmon at sea (corresponding to $2 \mathrm{SW}$ returning adult females) and $2+\mathrm{SW}$ (corresponding to $3 \mathrm{SW}$ returning adult females) salmon (Supplement 5), for each smolt year class $(y)$ and river using the following equations:

$$
\begin{aligned}
& \mathrm{SSG}_{2 \mathrm{SW}, y}=\frac{L_{1, y}-L_{\operatorname{tag} 1, y}}{L_{\operatorname{tag} 1, y}} \\
& \mathrm{SSG}_{3 \mathrm{SW}, y}=\frac{L_{2, y}-L_{\operatorname{tag} 2, y}}{L_{\operatorname{tag} 2, y}}
\end{aligned}
$$

where $L_{1}$ is the mean length $(\mathrm{cm})$ at recapture of all individuals released in year $y$ at the end of their first full year at sea $(1+\mathrm{SW}$ recaptured at sea in September-December), $L_{2}$ is the mean length at recapture of individuals from release year $y$ at the end of their second full year at sea $(2+$ SW recaptured at sea in September-December), $L_{\text {tag1 }}$ is the mean length $(\mathrm{cm})$ at tagging of the recaptured $1+\mathrm{SW}$ individuals and $L_{\text {tag2 }}$ is the mean length at tagging $(\mathrm{cm})$ of the individuals that were recaptured first as $2+$ SW individuals (Supplements 3 \& 5). Mean length estimates based on $<5$ recaptured individuals were excluded from the analyses to avoid biased growth estimates. Recaptures from the time period September-December were used, as salmon cease their growth during winter and spring before returning to their natal river for spawning (commonly starting to ascend their rivers during May, June and July; Whitlock et al. 2018). Thus, the size at the end of each growth season at sea reflects the size at return to the river for spawning.

\subsection{Statistical analysis}

We used linear regression analyses to test whether size-specific growth at sea contributes to explain variation in the reproductive potential in addition to the variation in reproductive potential explained by estimated survival at sea and number of released smolts in Dalälven and in Umeälven. For each river, linear regression models were fitted with the annual reproductive potential as the response variable and one set of models including the number of released smolt, growth and survival at sea as explanatory variables and another set of models disregarding growth at sea. No interaction between the 2 dominant smolt year classes (2SW and 3SW old returning adult females; Table S1) was included because densitydependent survival or growth at sea is not common for Atlantic salmon (Jonsson et al. 1998), and an interaction term between smolt year classes would, therefore, not have any biological meaning. However, an interaction within smolt year classes was included since a positive correlation between growth and survival could be expected, at least during the first time period spent at sea (Friedland et al. 2005, Peyronnet et al. 2007). After model fitting, model selection based on the Akaike's information criterion (AIC) was used (model(s) within $+2 \Delta$ AIC from the model with the lowest AIC was selected; Burnham \& Anderson 2004). Finally, the adjusted $\mathrm{R}^{2}$ of the selected model(s) was compared to see which explained most of the variation in the reproductive potential in Dalälven and Umeälven separately. Assumptions of homogenously distributed and normally distributed residuals were visually assessed via model evaluation plots (Fig. S11, Supplement 6) and all selected models fulfilled, to a satisfactory degree, the assumptions of linear regression models.

\section{RESULTS}

\subsection{Growth rate at sea}

The mean length at age increased with sea age but varied among smolt year classes for both Dalälven and Umeälven (Fig. S7). Also, the mean length at tagging of the recaptured $1+\mathrm{SW}$ and $2+\mathrm{SW}$ salmon differed both within and among smolt year classes (Fig. S8). Consequently, the mean SSG (\% length increase) of individuals corresponding to returning $2 \mathrm{SW}$ and $3 \mathrm{SW}$ adult salmon varied across years, and differently so for Dalälven and Umeälven (Fig. 2; Pearson correlation; 2SW comparison for Dalälven and Umeälven: $\mathrm{r}=0.43, t=2.82$, df $=35$, $\mathrm{p}<0.05$; 3SW comparison for Dalälven and Umeälven: $\mathrm{r}=0.60, t=3.64, \mathrm{df}=24, \mathrm{p}<0.05)$.

\subsection{Survival at sea}

The estimated survival at sea for returning 2SW and 3SW adults from each smolt year class varied 


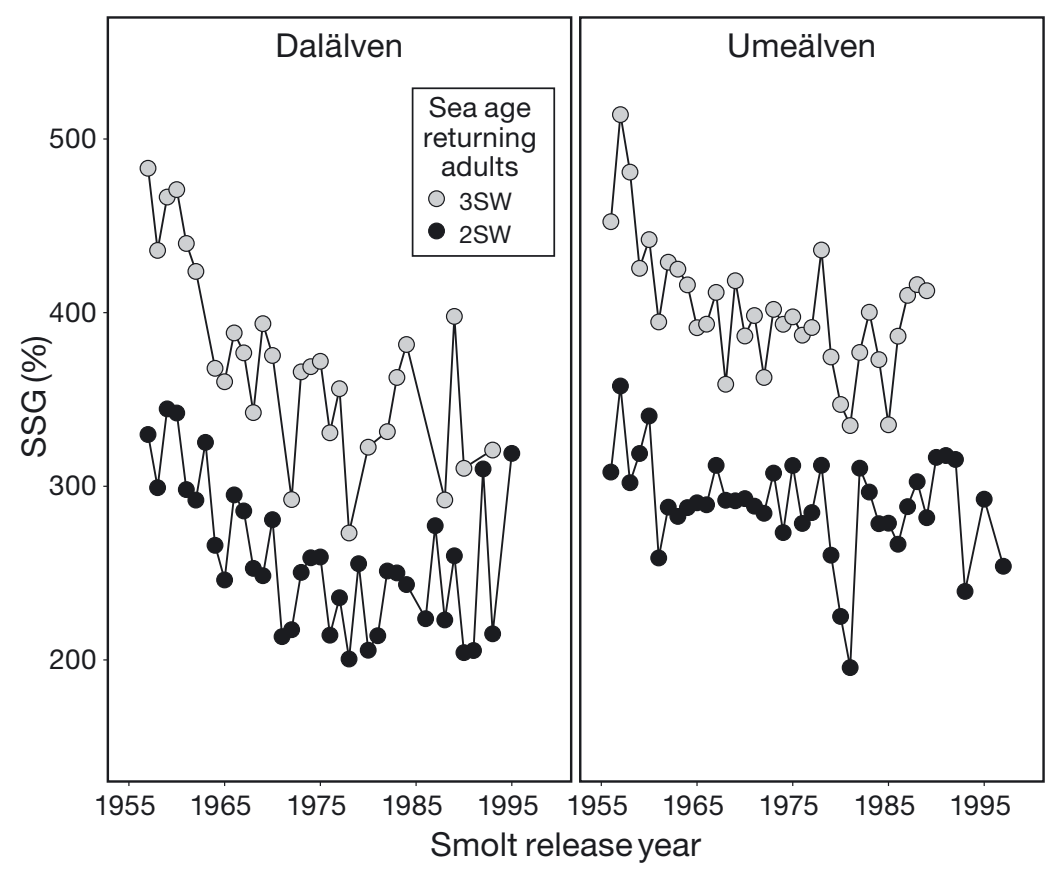

Fig. 2. Size-specific growth (SSG, \% length increase) at sea as mean of individuals corresponding to 2 and 3 sea winter-aged salmon (2SW and 3SW), calculated for smolt year classes released in 1956-1996, originating from the rivers Dalälven and Umeälven

\subsection{Growth at sea contributes to explain population-specific reproductive potential}

For both Dalälven and Umeälven, the selected model(s) for explaining their reproductive potential included growth at sea (Table 1). All models for Dalälven including growth at sea had a lower $\triangle$ AIC and higher explanatory power compared to models without growth at sea (Table 1). For Dalälven, the selected model included growth at sea and explained $62 \%$ of the variation in annual reproductive potential (Table 1 ; no other model had $\triangle$ AIC $<4$ ). For Umeälven, 1 of the 2 selected models included growth at sea (Table 1). However, the model including growth at sea and the second best model, which lacked growth, were very similar as their differences in AIC $(\triangle \mathrm{AIC}=0.95)$ and adjusted $\mathrm{R}^{2}$ (39 vs. $38 \%$, with and without growth at sea, respec-

over time in both populations (Fig. S9). The survival at sea for 2SW salmon originating from Dalälven and Umeälven was correlated but was far from identical (Pearson correlation; 2SW: $\mathrm{r}=0.50, t=3.7, \mathrm{df}=41, \mathrm{p}<$ $0.05)$. Likewise, the survival at sea for $3 \mathrm{SW}$ salmon originating from Dalälven and Umeälven was correlated but not identical (Pearson correlation; 3SW: $\mathrm{r}=$ $0.51, t=3.8, \mathrm{df}=41, \mathrm{p}<0.05$ ). tively) were small (Table 1). Thus, including growth at sea estimates more than doubled the amount of the explained variation in the reproductive potential for Dalälven, while only marginally increasing it for Umeälven. Still, predictions of the reproductive potential in both rivers differed depending on whether growth at sea was included as an explanatory variable or not (Fig. 3).

Table 1. Model setup and statistics ( $F, \Delta$ Akaike's information criterion [ $\Delta \mathrm{AIC}], \mathrm{R}^{2}$ and adjusted $\mathrm{R}^{2}$ [Adj. $\left.\mathrm{R}^{2}\right]$ ) with or without inclusion of growth at sea (size-specific growth, SSG) of 2 or 3 sea winter-aged (2SW and 3SW) returning adult salmon explaining variation in the annual reproductive potential in the rivers Dalälven and Umeälven. Models are sorted according to their AIC-values, lowest (highlighted in bold) to highest, for each river. Releases: annual number of released smolts for the smolt year class corresponding to 2SW and 3SW returning adult females. Survival: survival at sea for each smolt year class corresponding to 2SW and 3SW returning adult females

\begin{tabular}{|c|c|c|c|c|c|}
\hline Population & Model & $F(\mathrm{df})$ & $\Delta \mathrm{AIC}$ & $\mathrm{R}^{2}$ & Adj. $R^{2}$ \\
\hline \multirow[t]{6}{*}{ Dalälven } & Releases $2 S W \times$ Survival $2 S W \times$ SSG $2 S W+$ Releases $3 S W \times$ Survival $3 S W \times$ SSG $3 S W$ & $3.96(14,11)$ & 0.00 & 0.84 & 0.62 \\
\hline & Releases 2SW $\times$ Survival 2SW + SSG 2SW + Releases 3SW $\times$ Survival 3SW + SSG 3SW & $4.60(8,17)$ & 4.82 & 0.68 & 0.54 \\
\hline & Releases 2SW + Survival 2SW + SSG 2SW + Releases 3SW + Survival 3SW + SSG 3SW & $3.23(6,19)$ & 12.48 & 0.51 & 0.35 \\
\hline & Releases 2SW × Survival 2SW + Releases 3SW × Survival 3SW & $2.52(6,19)$ & 15.53 & 0.44 & 0.27 \\
\hline & Releases $2 \mathrm{SW} \times \mathrm{SSG} 2 \mathrm{SW}+$ Survival $2 \mathrm{SW}+$ Releases $3 \mathrm{SW} \times \mathrm{SSG} 3 \mathrm{SW}+$ Survival $3 \mathrm{SW}$ & $2.31(8,17)$ & 15.63 & 0.52 & 0.30 \\
\hline & Releases 2SW + Survival 2SW + Releases 3SW + Survival 3SW & $1.70(4,21)$ & 19.50 & 0.24 & 0.10 \\
\hline \multirow[t]{6}{*}{ Umeälven } & Releases $2 \mathrm{SW} \times$ Survival $2 \mathrm{SW} \times \mathrm{SSG} 2 \mathrm{SW}+$ Releases $3 \mathrm{SW} \times$ Survival $3 \mathrm{SW} \times \mathrm{SSG} 3 \mathrm{SW}$ & $1.93(14,6)$ & 0.00 & 0.82 & 0.39 \\
\hline & Releases 2SW + Survival 2SW + Releases 3SW + Survival 3SW & $4.11(4,16)$ & 0.95 & 0.51 & 0.38 \\
\hline & Releases 2SW + Survival 2SW + SSG 2SW + Releases 3SW + Survival 3SW + SSG 3SW & $3.06(6,14)$ & 2.20 & 0.57 & 0.38 \\
\hline & Releases $2 \mathrm{SW} \times \mathrm{SSG} 2 \mathrm{SW}+$ Survival $2 \mathrm{SW}+$ Releases $3 \mathrm{SW} \times \mathrm{SSG} 3 \mathrm{SW}+$ Survival 3SW & $2.57(8,12)$ & 2.85 & 0.63 & 0.39 \\
\hline & Releases $2 \mathrm{SW} \times$ Survival $2 \mathrm{SW}+$ Releases $3 \mathrm{SW} \times$ Survival 3SW & $2.53(6,14)$ & 4.37 & 0.52 & 0.31 \\
\hline & Releases $2 \mathrm{SW} \times$ Survival $2 \mathrm{SW}+\mathrm{SSG} 2 \mathrm{SW}+$ Releases $3 \mathrm{SW} \times$ Survival $3 \mathrm{SW}+\mathrm{SSG} 3 \mathrm{SW}$ & $2.06(8,12)$ & 5.65 & 0.58 & 0.30 \\
\hline
\end{tabular}



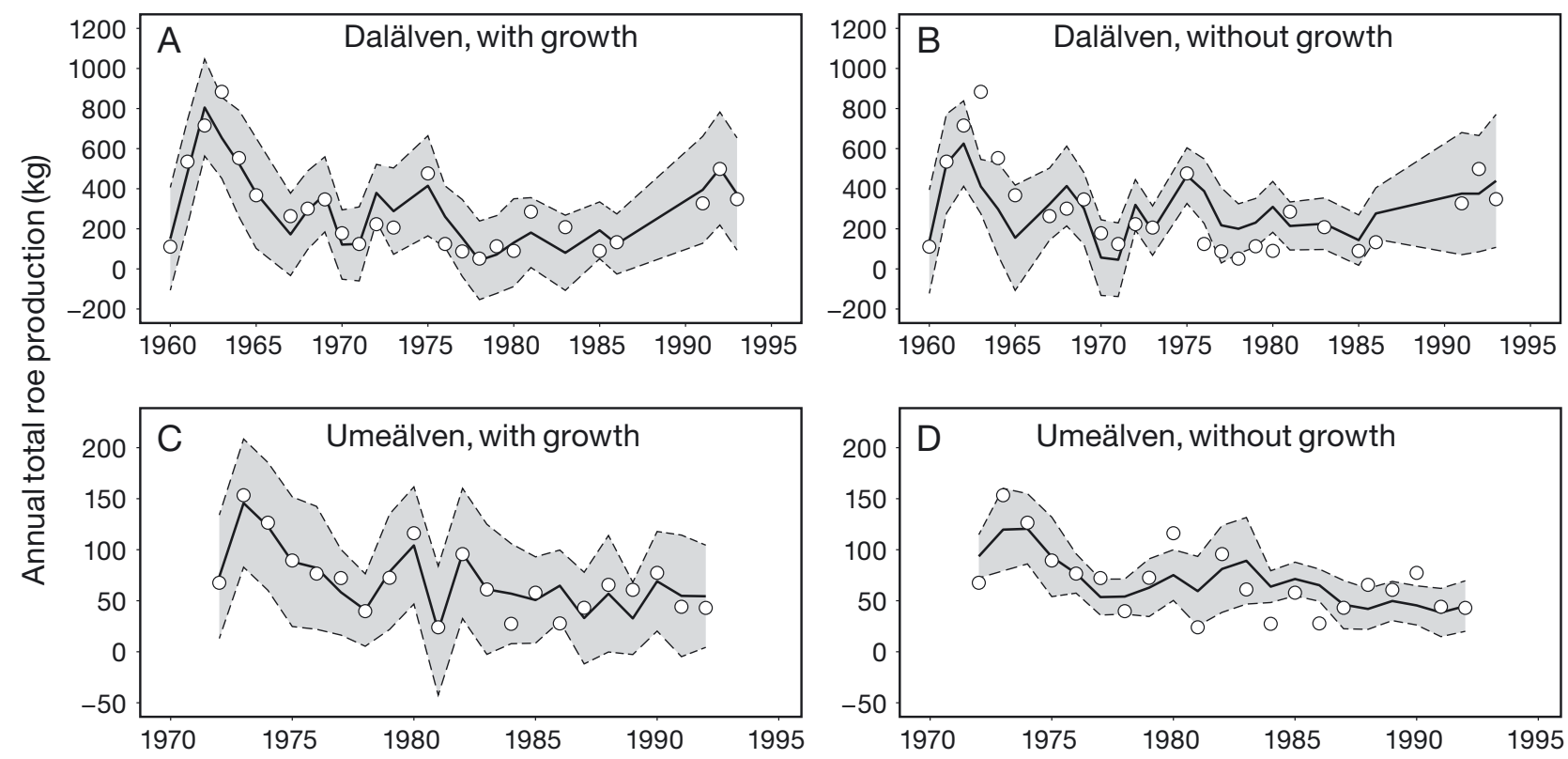

Fig. 3. Observed (white circles) and predicted (solid lines) reproductive potential (estimated total annual roe production) of salmon populations from $(A, B)$ Dalälven and $(C, D)$ Umeälven, predicted using the selected model (based on Akaike's information criterion) that either $(A, C)$ includes or $(B, D)$ excludes growth at sea. Dashed lines show the $95 \%$ confidence interval of the predicted annual total roe production of salmon

\section{DISCUSSION}

Little is known about whether variation in growth at sea influences variation in population size for Atlantic salmon. We combined long-term data sets of smolt year class abundance, survival and growth at sea, returning adult female length distributions and size-specific individual fecundity data for 2 salmon populations sharing the same sea and demonstrate that body growth at sea contributes to explaining variation in the reproductive potential of 2 Baltic Sea salmon populations. However, the extent to which body growth explained variation in the reproductive potential differed between our 2 study populations. This suggests that growth variation at sea could be an important food-dependent process to consider when studying variation in the recovery and dynamics of salmon populations.

Our results suggest that variation in body growth at sea can affect population-level processes such as their reproductive potential. Similarly, it has previously been shown in a theoretical study that differences in body condition of returning adult females can affect Atlantic salmon population dynamics (Susdorf et al. 2018). Growth and body condition of salmon at sea both depend on prey availability (Jacobson et al. 2018). In addition, prey availability at sea has been shown to co-vary with survival of Baltic salmon (Mäntyniemi et al. 2012). Consequently, changes in prey availability (Jacobson et al. 2018), prey types (Renkawitz et al. 2015, Keinänen et al. 2017) and prey energy content (Renkawitz et al. 2015) at sea may potentially affect salmon population dynamics (Friedland et al. 2005, 2009). Several of the common fish prey species for Atlantic salmon in the North Atlantic Ocean and in the Baltic Sea are commercially exploited (e.g. capelin Mallotus villosus in the northeast Atlantic [Gudmundsdottir \& Vilhjàlmsson 2002, Renkawitz et al. 2015, Dixon et al. 2017] and sprat Sprattus sprattus in the Baltic Sea [Karlsson et al. 1999, Hansson et al. 2001, Ojaveer \& Kalejs 2010, Jacobson et al. 2018]), potentially affecting the amount of available prey at sea. Therefore, considering changes in the abundance and size-structure of salmon prey, changes in fisheries targeting salmon prey species (using a multi-species approach) and variation in salmon growth and survival at sea could be necessary to increase our understanding of how salmon populations respond to changes at sea.

Despite the fact that our 2 study populations originate from rivers entering the same sea (the Baltic Sea), they did not exhibit the same growth rates at sea. This growth difference could arise if salmon experience different feeding opportunities at sea, e.g. via differences in prey availability, or it could be due to the genetic differences between our 2 study populations (Ståhl 1987, Vasemägi et al. 2005, Whitlock et al. 2018, Östergren et al. 2020). Salmon from Daläl- 
ven have a more variable distribution pattern at sea and utilize a larger area in the Baltic Sea for feeding and growth compared to salmon from Umeälven, which are more restricted to the southern Baltic Sea (Jacobson et al. 2020). Given that the size-specific prey availability of salmon varies spatially in the Baltic Sea (Jacobson et al. 2018), the growth potential at sea likely differed between salmon from Dalälven and Umeälven during our study period. Survival at sea also varies over time and was not identical between the 2 populations. The survival estimate accounts for differences in the spatial distribution in recaptures between Dalälven and Umeälven (Supplement 4; Jacobson et al. 2020). Consequently, as the fisheries targeting Baltic salmon at sea have not been homogenously distributed during our study period (ICES 2019), survival at sea is not expected to be identical between the 2 populations. Thus, as both growth and survival at sea can differ between populations entering the same sea, accounting for such differences may be important for understanding why populations can have asynchronous dynamics and respond differently to changes in their sea habitat.

We show that variation in growth at sea can affect the reproductive potential of salmon populations, which determines the upper limit of juveniles hatching in the river. However, it is well known for many salmonid species that the abundance of juveniles that survive and eventually leave the river as smolts is highly density dependent due to competition among juveniles for food and space in the river (Achord et al. 2003, Einum \& Nislow 2005, Einum et al. 2006). As a result, the number of spawners can affect the strength of the link between variation in performance of salmon at sea and their population dynamics. When the number of spawners is low, such that the population size is regulated by the number and body size of spawners, the link between growth at sea and population abundance is likely strong. In the opposite case, when the abundance of spawners is so high that the population size is regulated by density dependence in the river, the link between body growth at sea and population abundance is likely weak. According to ICES (2019), the production of smolts in many of the wild Baltic salmon populations is currently limited by density dependence in the river and not by the reproductive output of the population, but for some wild populations (e.g. Simojoki, Rickleån, Lögde and Emån) an increase in adult spawners is estimated to increase the number of produced smolts. For our 2 study populations, however, smolt production is decoupled from the abundance of spawners, as these are hatchery-reared populations sustained via an- nually renewed broodstock. Still, accounting for whether the population size is governed by density dependence in the river or by its reproductive output could be important when assessing whether fooddependent processes at sea such as growth could affect the dynamics and recovery among salmon populations sharing the same sea.

There are biological reasons to explain why the link between growth at sea and population-level reproductive potential can vary among salmon populations entering the same sea. However, our findings that body growth explained a greater amount of variation in reproductive potential in Dalälven than in Umeälven could also be due to differences in the observational data. The trap in Umeälven is located further upstream in the system compared to Dalälven and is affected by variation in river discharge, which varied during our study period (Rivinoja 2005). In addition, the number of years of available data differs between our 2 study populations and is lower for Umeälven (n $=21$ vs. $\mathrm{n}=26$ for Dalälven). This could be one reason why the explanatory power when adding growth at sea to our models increased less for Umeälven than for Dalälven, as inclusion of body growth increases model complexity substantially, and the degrees of freedom are limited. However, despite the lower number of data points for Umeälven compared to Dalälven, growth at sea was included in 1 of the 2 selected models for Umeälven. Thus, it can be important to consider growth at sea in order to understand annual variation in the reproductive potential in some salmon populations, although it may not be as important in others.

\section{CONCLUSION}

The fact that body growth at sea can increase the explained variation in the population-specific reproductive potential of Baltic salmon suggests that consideration of variation in food-dependent processes at sea can be important to increase our understanding of the dynamics of anadromous fish populations. However, as the size of anadromous populations can either be regulated by density dependence in the river or by the annual reproductive output of spawning adults, the importance of survival and body growth at sea for population dynamics can differ among populations depending on which life stage regulates population size. Differences in how sensitive populations are to variation in body growth at sea could be one reason why populations respond differently to changes in their shared feeding habitat. 
Therefore, we argue that safeguarding suitable feeding opportunities at sea via multi-species management approaches should be considered in future salmon management.

Acknowledgements. We thank everyone that has been involved in collecting the data used in our study and those that have reported recaptures of tagged salmon. We further thank 3 anonymous reviewers for helpful comments on earlier drafts. This work resulted in part from the BONUS GOHERR project supported by BONUS (Art 185), funded jointly by the EU and the Swedish Research Council Formas.

\section{LITERATURE CITED}

Aas Ø, Einum S, Klemetsen A, Skurdal J (2011) Atlantic salmon ecology. Wiley-Blackwell, Oxford

Achord S, Levin PS, Zabel RW (2003) Density-dependent mortality in Pacific salmon: the ghost of impacts past? Ecol Lett 6:335-342

Bacon PJ, Palmer SCF, MacLean JC, Smith GW, Whyte BDM, Gurney WSC, Youngson AF (2009) Empirical analyses of the length, weight, and condition of adult Atlantic salmon on return to the Scottish coast between 1963 and 2006. ICES J Mar Sci 66:844-859

Barneche DR, Robertson DR, White CR, Marshall DJ (2018) Fish reproductive-energy output increases disproportionately with body size. Science 360:642-645

Burnham KP, Anderson DR (2004) Multimodel inference: understanding AIC and BIC in model selection. Sociol Methods Res 33:261-304

Chaput G (2012) Overview of the status of Atlantic salmon (Salmo salar) in the North Atlantic and trends in marine mortality. ICES J Mar Sci 69:1538-1548

de Eyto E, White J, Boylan P, Clarke B and others (2015) The fecundity of wild Irish Atlantic salmon Salmo salar L. and its application for stock assessment purposes. Fish Res 164:159-169

Dixon HJ, Dempson JB, Sheehan TF, Renkawitz MD, Power M (2017) Assessing the diet of North American Atlantic salmon (Salmo salar L.) off the West Greenland coast using gut content and stable isotope analyses. Fish Oceanogr 26: $555-568$

* Einum S, Nislow KH (2005) Local-scale density-dependent survival of mobile organisms in continuous habitats: an experimental test using Atlantic salmon. Oecologia 143: 203-210

* Einum S, Sundt-Hansen L, Nislow KH (2006) The partitioning of density-dependent dispersal, growth and survival throughout ontogeny in a highly fecund organism. Oikos 113:489-496

Fleming IA (1996) Reproductive strategies of Atlantic salmon: ecology and evolution. Rev Fish Biol Fish 6:379-416

Friedland KD, Chaput G, MacLean JC (2005) The emerging role of climate in post-smolt growth of Atlantic salmon. ICES J Mar Sci 62:1338-1349

Friedland KD, MacLean JC, Hansen LP, Peyronnet AJ and others (2009) The recruitment of Atlantic salmon in Europe. ICES J Mar Sci 66:289-304

Friedland KD, Shank BV, Todd CD, McGinnity P, Nye JA (2014) Differential response of continental stock complexes of Atlantic salmon (Salmo salar) to the Atlantic Multidecadal Oscillation. J Mar Syst 133:77-87
Gudmundsdottir A, Vilhjàlmsson H (2002) Predicting total allowable catches for Icelandic capelin, 1978-2001. ICES J Mar Sci 59:1105-1115

Hansson S, Karlsson L, Ikonen E, Christensen $\mathrm{O}$ and others (2001) Stomach analyses of Baltic salmon from 1959-1962 and 1994-1997: possible relations between diet and yolk-sac-fry mortality (M74). J Fish Biol 58: 1730-1745

*Hixon MA, Johnson DW, Sogard SM (2014) BOFFFFs: on the importance of conserving old-growth age structure in fishery populations. ICES J Mar Sci 71:2171-2185

* ICES (2010) Report of the study group on biological characteristics as predictors of salmon abundance (SGBICEPS), 24-26 November 2009, ICES Headquarters, Copenhagen, ICES CM/SSGEF 03:158. https://www.ices.dk/sites/pub/ CM\%20Doccuments/CM-2010/SSGEF/SGBICEPS10.pdf

ICES (2013) Report of the Baltic Salmon and Trout Assessment Working Group (WGBAST), 3-12 April 2013, Tallinn, Estonia. ICES CM ACOM: 08

ICES (2018) Report of the Baltic Salmon and Trout Assessment Working Group (WGBAST), 20-28 March 2018, Turku, Finland. ICES CM ACOM: 10

ICES (2019) Baltic Salmon and Trout Assessment Working Group (WGBAST), Saint Petersburg. 27 March-4 April 2019. ICES Sci Rep 1:23

Jacobson P, Gårdmark A, Östergren J, Casini M, Huss M (2018) Size-dependent prey availability affects diet and performance of predatory fish at sea: a case study of Atlantic salmon. Ecosphere 9:e02081

Jacobson P, Gårdmark A, Huss M (2020) Population and sizespecific distribution of Atlantic salmon Salmo salar in the Baltic Sea over five decades. J Fish Biol 96:408-417

Jensen AJ, Finstad B, Fiske P, Forseth T, Rikardsen AH, Ugedal O (2018) Relationship between marine growth and sea survival of two anadromous salmonid fish species. Can J Fish Aquat Sci 75:621-628

Jonsson N, Jonsson B, Hansen LP (1998) The relative role of density-dependent and density-independent survival in the life cycle of Atlantic salmon Salmo salar. J Anim Ecol 67:751-762

Karlsson L, Karlström Ö (1994) The Baltic salmon (Salmo salar L.): its history, present situation and future. Dana 10:61-85

Karlsson L, Ikonen E, Mitans A, Hansson S (1999) The diet of salmon (Salmo salar) in the Baltic Sea and connections with the M74 syndrome. Ambio 28:37-42

Keinänen M, Käkelä R, Ritvanen T, Myllylä T, Pönni J, Vuorinen PJ (2017) Fatty acid composition of sprat (Sprattus sprattus) and herring (Clupea harengus) in the Baltic Sea as potential prey for salmon (Salmo salar). Helgol Mar Res 71:4

KLarsson PO (1984) Growth of Baltic salmon Salmo salar in the sea. Mar Ecol Prog Ser 17:215-226

Lorenzen K (1996) The relationship between body weight and natural mortality in juvenile and adult fish: a comparison of natural ecosystems and aquaculture. J Fish Biol 49:627-647

* Lugert V, Thaller G, Tetens J, Schulz C, Krieter J (2016) A review on fish growth calculation: multiple functions in fish production and their specific application. Rev Aquacult 8:30-42

Mäntyniemi S, Romakkaniemi A, Dannewitz J, Palm S and others (2012) Both predation and feeding opportunities may explain changes in survival of Baltic salmon postsmolts. ICES J Mar Sci 69:1574-1579 
Ohlberger J, Edeline E, Vollestad LA, Stenseth NC, Claessen D (2011) Temperature-driven regime shifts in the dynamics of size-structured populations. Am Nat 177:211-223

Ojaveer E, Kalejs M (2010) Ecology and long-term forecasting of sprat (Sprattus sprattus balticus) stock in the Baltic Sea: a review. Rev Fish Biol Fish 20:203-217

弚stergren J, Palm S, Gilbey J, Dannewitz J (2020) Close relatives in population samples: evaluation of the consequences for genetic stock identification. Mol Ecol Resour 20:498-510

Persson L, de Roos AM (2013) Symmetry breaking in ecological systems through different energy efficiencies of juveniles and adults. Ecology 94:1487-1498

Persson L, Amundsen PA, de Roos AM, Klemetsen A, Knudsen R, Primicerio R (2007) Culling prey promotes predator recovery - alternative states in a whole-lake experiment. Science 316:1743-1746

Petersson E, Järvi T, Steffner NG, Ragnarsson B (1996) The effect of domestication on some life history traits of sea trout and Atlantic salmon. J Fish Biol 48:776-791

* Peyronnet A, Friedland KD, Maoileidigh NÓ, Manning M, Poole WR (2007) Links between patterns of marine growth and survival of Atlantic salmon Salmo salar, L. J Fish Biol 71:684-700

Renkawitz MD, Sheehan TF, Dixon HJ, Nygaard R (2015) Changing trophic structure and energy dynamics in the Northwest Atlantic: implications for Atlantic salmon feeding at West Greenland. Mar Ecol Prog Ser 538: $197-211$

Rivinoja P (2005) Migration problems of Atlantic salmon (Salmo salar L.) in flow regulated rivers. PhD thesis, Swedish University of Agricultural Sciences, Umeå

Romakkaniemi A, Perä I, Karlsson L, Jutila E, Carlsson U, Pakarinen T (2003) Development of wild Atlantic salmon stocks in the rivers of the northern Baltic Sea in

Editorial responsibility: Alejandro Gallego,

Aberdeen, UK

Reviewed by: 3 anonymous referees response to management measures. ICES J Mar Sci 60: 329-342

Soto DX, Trueman CN, Samways KM, Dadswell MJ, Cunjak RA (2018) Ocean warming cannot explain synchronous declines in North American Atlantic salmon populations. Mar Ecol Prog Ser 601:203-213

Ståhl G (1987) Genetic population structure of Atlantic salmon. In: Ryman N, Utter F (eds) Population genetics and fishery management. Washington Sea Grant Program/ University of Washington Press, Seattle, WA, p 121-140

Susdorf R, Salama NKG, Lusseau D (2018) Influence of body condition on the population dynamics of Atlantic salmon with consideration of the potential impact of sea lice. J Fish Dis 41:941-951

* Thorpe JE, Miles MS, Keay DS (1984) Developmental rate, fecundity and egg size in Atlantic salmon, Salmo salar L. Aquaculture 43:289-305

* Todd CD, Hughes SL, Marshall CT, MacLean JC, Lonergan ME, Biuw EM (2008) Detrimental effects of recent ocean surface warming on growth condition of Atlantic salmon. Glob Change Biol 14:958-970

*van Leeuwen A, de Roos AM, Persson L (2008) How cod shapes its world. J Sea Res 60:89-104

*Vasemägi A, Gross R, Paaver T, Koljonen ML, Nilsson J (2005) Extensive immigration from compensatory hatchery releases into wild Atlantic salmon population in the Baltic sea: spatio-temporal analysis over 18 years. Heredity 95:76-83

Whitlock RE, Kopra J, Pakarinen T, Jutila E and others (2017) Mark-recapture estimation of mortality and migration rates for sea trout (Salmo trutta) in the northern Baltic sea. ICES J Mar Sci 74:286-300

*Whitlock RE, Mäntyniemi S, Palm S, Koljonen ML, Dannewitz J, Östergren J (2018) Integrating genetic analysis of mixed populations with a spatially explicit population dynamics model. Methods Ecol Evol 9:1017-1035

Submitted: June 17, 2020

Accepted: April 21, 2021

Proofs received from author(s): August 1, 2021 